\title{
REVALUATING AIRCRAFT LEASING CONTRACTS IN THE PANDEMIC ERA: NAVIGATING THE CHALLENGES OF INVOKING FORCE-MAJEURE BY APPLYING HARDSHIP UNDER INTERNATIONAL COMMERCIAL LAW
}

Tanya Agarwal

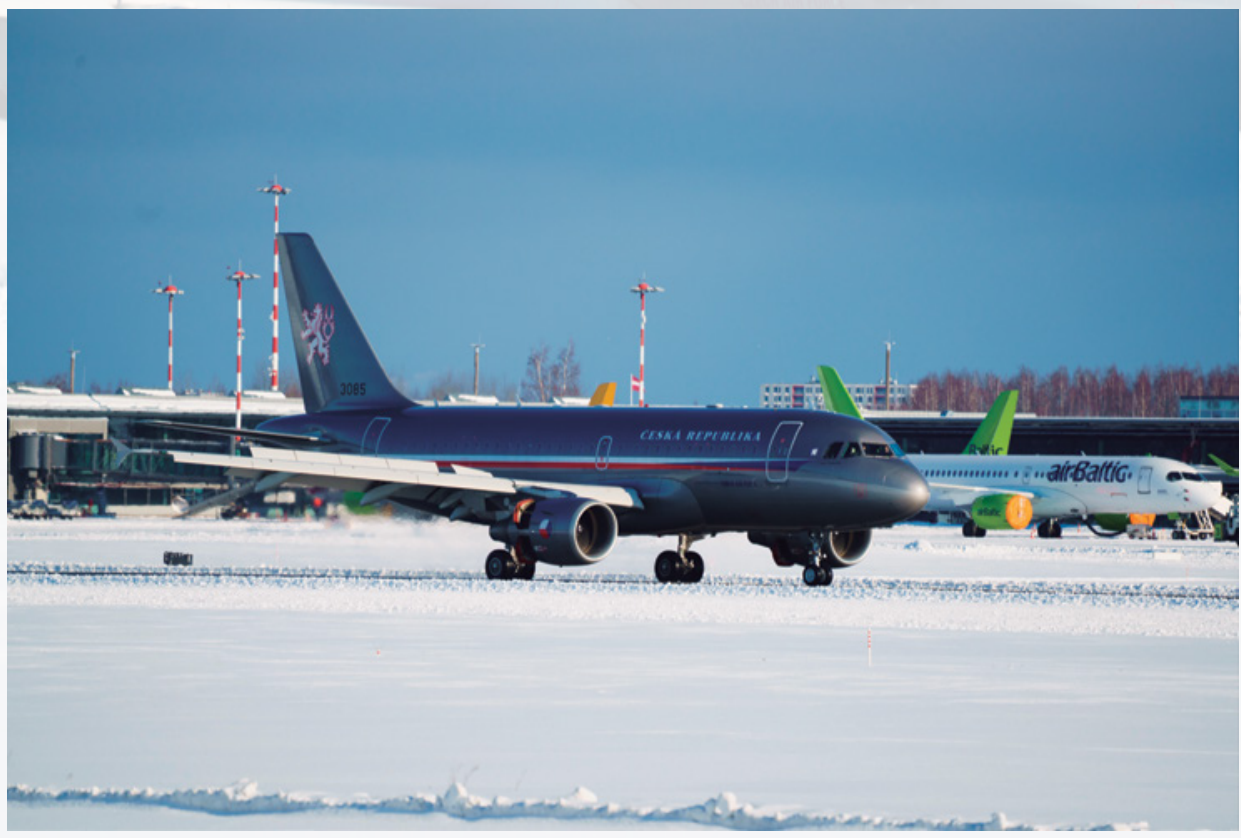





\title{
REVALUATING AIRCRAFT LEASING CONTRACTS IN THE PANDEMIC ERA: NAVIGATING THE CHALLENGES OF INVOKING FORCE-MAJEURE BY APPLYING HARDSHIP UNDER INTERNATIONAL COMMERCIAL LAW
}

\author{
Tanya Agarwal \\ Amity LaW School, Delhi, India
}

\begin{abstract}
The majority of aircraft are acquired through leasing agreements, and the financial burden is on the lessor due to their financing of heavy equipment for the lessee in these agreements. Therefore, to ensure that the lessee fulfills their lease payment to the lessor, a "hell or high-water" clause is drafted in the contract. This enforces payment by the lessee regardless of any circumstantial changes that might make it difficult for them to pay. However, due to the pandemic, airlines have suffered from a severe cash crunch making it difficult for them to honor their upcoming contractual obligations. Airline companies are debating whether to invoke force majeure in these contracts to excuse nonperformance and avoid damages; nevertheless, considering developments in Private International Air Law and the nature of the contract, taking such measures will be difficult. This paper proposes to apply the hardship clause codified in the UNIDROIT Principles of International Commercial Contracts so that airlines can renegotiate the contract with their lessors instead of completely avoiding their contractual obligation. This will provide breathing space for the lessee, while ensuring that their obligation towards the lessor is maintained during the pandemic.
\end{abstract}

Keywords: Aircraft leasing agreement, hell or high-water clause, force majeure, hardship, nonperformance, renegotiation.

About the author: 4th Year - Bachelor of Arts and Bachelor of Legislative Law (Hons.) Amity Law School, Delhi (GGSIPU), India. tanu.in70@gmail.com

Received: May 21, 2021; Reviewed: September 15, 2021; Accepted: October 30, 2021. 


\title{
REVALUACIÓN DE LOS CONTRATOS DE ARRENDAMIENTO DE AERONAVES EN LA ERA DE LA PANDEMIA: CÓMO NAVEGAR LOS RETOS DE INVOCAR LA FUERZA MAYOR MEDIANTE LA APLICACIÓN DE ONEROSIDAD EXCESIVA EN EL DERECHO MERCANTIL INTERNACIONAL
}

\author{
Tanya Agarwal \\ Amity Law School, Delhi, India
}

\section{Resumen}

La mayoría de las aeronaves se adquieren mediante contratos de leasing, y la carga financiera recae en el arrendador debido a su financiación de equipos pesados para el arrendatario en estos contratos. Por lo tanto, para garantizar que el arrendatario cumpla con el pago del arrendamiento al arrendador, se redacta en el contrato una cláusula "contra viento y marea". Esto obliga al pago por parte del arrendatario independientemente de cualquier cambio circunstancial que les dificulte el pago. Sin embargo, debido a la pandemia, las compañías aéreas han sufrido una grave escasez de efectivo que les dificulta el cumplimiento de sus próximas obligaciones contractuales. Las compañías aéreas están debatiendo la posibilidad de invocar la fuerza mayor en estos contratos para excusar el incumplimiento y evitar daños y perjuicios; no obstante, teniendo en cuenta los desarrollos en Derecho Aéreo Internacional Privado y la naturaleza del contrato, será difícil tomar tales medidas. Este documento propone aplicar la onerosidad excesiva codificada en los Principios de Unidroit sobre Contratos Comerciales Internacionales para que las compañías aéreas puedan renegociar el contrato con los arrendadores en lugar de eludir completamente su obligación contractual. Esto proporcionará un respiro al arrendatario y también garantizará que su obligación hacia el arrendador se mantenga durante la pandemia.

Palabras clave: contrato de arrendamiento de aeronaves, cláusula "contra viento y marea", fuerza mayor, onerosidad excesiva, incumplimiento, renegociación

La autora: $4^{\circ}$ año - Licenciatura en Artes y Licenciatura en Derecho Legislativo (Hons.) Amity Law School, Delhi (GGSIPU), India. tanu.in70@gmail.com

Recibido: 21 de mayo de 2021; evaluado: 15 de septiembre de 2021; aceptado: 30 de octubre de 2021. 


\title{
REAVALIAÇÃO DOS CONTRATOS DE ARRENDAMENTO DE AERONAVES NA ERA DA PANDEMIA: COMO NAVEGAR NOS DESAFIOS DA INVOCAÇÃO DA FORÇA MAIOR APLICANDO A ONEROSIDADE EXCESSIVA NO DIREITO INTERNACIONAL DO COMÉRCIO
}

\author{
Tanya Agarwal \\ Amity LaW School, Delhi, India
}

\section{Resumo}

A maioria das aeronaves são adquiridas por meio de contratos de leasing, e a carga financeira recai sobre o locador devido ao seu financiamento de equipamentos pesados para os locatários nesses contratos. Portanto, para garantir que o locatário cumpra com o pagamento do aluguel ao locador, uma cláusula "contra todas as probabilidades" é redigida no contrato. Isso obriga o locatário a efetuar o pagamento, independentemente de qualquer mudança circunstancial que dificulte isso. No entanto, devido à pandemia, as companhias aéreas têm sofrido uma forte escassez de dinheiro que dificulta o cumprimento de suas obrigações contratuais. As companhias aéreas estão discutindo a possibilidade de invocar força maior nesses contratos para justificar o não cumprimento e evitar danos. No entanto, levando em conta os desenvolvimentos do Direito Aéreo Internacional Privado e a natureza do contrato, será difícil tomar tais medidas. Este documento propõe aplicar a onerosidade excessiva codificada nos Princípios de UNIDROIT sobre contratos comerciais internacionais para que as companhias aéreas possam renegociar o contrato com locadores em vez de evadir completamente suas obrigações contratuais. Isso proporcionará tranquilidade ao locatário e garantirá que sua obrigação com o locador seja mantida durante a pandemia.

Palavras-chave: contrato de arrendamento de aeronaves, cláusula "contra todas as probabilidades", força maior, onerosidade excessiva, descumprimento, renegociação

O autor: Bacharel do $4^{\circ}$ ano em Artes e Bacharel em Direito Legislativo (Hons.) Amity Law School, Delhi (GGSIPU), India. tanu.in70@gmail.com

Recebido: 21 de maio de 2021; avaliado: 15 de setembro de 2021; aprovado: 30 de outubro de 2021. 


\section{Introduction}

In the twenty-first century, airline development is a sign of globalization. They connect the world with a simple thought of 'one flight away', but the outbreak of COVID-19 has severely affected their running operations. Global lockdowns and international border controls have hampered their financial position, thereby forcing them to reassess their obligations towards acquisition contracts. Most commercial contracts offer a provision of Force Majeure remedy, which allows parties to excuse their liability for non-performance during an unforeseeable event that is beyond their control. However, airlines acquire their aircraft on contracts that do not excuse them from paying their liability based on absolute obligations of the "hell or high-water" clause. Therefore, irrespective of any event, airline operators must fulfil their performance to pay and take delivery of the aircraft under acquisition contracts. However, the pandemic has pushed the airlines into a quandary, making them question their position regarding such absolute obligations, that is, whether they are still bound to fulfil them when mere survival to stay afloat has become a financial battle.

This paper is an attempt to understand the impact of COVID-19 on the contractual obligation of aircraft operators. It begins by initially providing an insight into the nature and regulation of aircraft acquisition contracts under international law and understanding the need for such obligations contained within aircraft lease agreements. It seeks to study whether Force Majeure as interpreted under national and international jurisdiction holds valid under these contracts based on lease agreements enclosed with absolute obligations. The paper is limited to acquiring aircraft on lease as any other way may provide airlines with different remedies from contractual obligations. The author has attempted to propose applying the Rebus sic stantibus principle of Hardship as provided under UNIDROIT International commercial law on aircraft acquisition contracts. It may provide temporary relief to airline operators to re-negotiate and adjust their lease agreements to strike a balance. The author has also suggested other recourse available to airline companies to use their acquired aircraft without exhausting their liquidity during this pandemic.

\section{Aircraft acquisition contract}

There has been an exponential increase in the commercial aviation industry in recent years, making airlines acquire more aircraft through purchasing or leasing 
contracts. ${ }^{1}$ These contracts provide airlines with several funding arrangements and create different kinds of ownership obligations. Airlines can purchase aircraft either from their own or any other credit resource available to them. However, it is a capital-intensive task, so most airlines are inclined to lease an aircraft because the nature of the aviation business is constantly fluctuating. ${ }^{2}$ Leasing provides airlines with several economic advantages which allows them to grow and remain flexible. ${ }^{3}$ Therefore, more than half of the airlines choose to operate their aircraft on leasing contracts. ${ }^{4}$ The main spirit of a lease is the right to possess and use the leased asset in exchange for consideration. The Cape Town Convention defines a lease as, 'an agreement by which one person (the lessor) grants a right to possession or control of an object (with or without an option to purchase) to another person (the lessee) in return for a rental or other payment'.

The International Accounting Standards Board has classified leases into finance and operating leases. ${ }^{6}$ The main difference between them is that the former transfers the substantial risk and reward on the lessee makes him the owner of the leased aircraft once the lease is paid, and in case of the latter no such transfer takes place, the lessee has the option to return the aircraft to the lessor. Different kinds of lease contracts are generally tailor-made and designed on the basis of a model lease pattern accommodating the interest of the parties. ${ }^{7}$ However, the nature of the absolute contractual obligations under these contracts regarding the performance mostly remains the same irrespective of the type of lease, thereby creating no significant difference in the nature of lessor-lessee relationship. Private International Air Law has attempted to harmonize a standard legal regime that can act as an authority to determine the nature of these contracts and guide the global aviation industry, which conducts business across borders.

1 Eva Endrizalova and others, 'Operating Lease as a Specific Form of Airlines Outsourcing' (18th international scientific conference Business Logistics in Modern Management, November 2018). <https://www.researchgate. net/publication/328829802_Operating_Lease_As_A_Specific_Form_Of_Airlines_Outsourcing $>$ accessed 2 April 2021.

2 Hortencia Jimenez, 'Commercial Aircraft Leasing and its Booming Complexities' (MSc. Aviation Administration thesis, Middle Tennessee State University 2017).

3 Lease Europe and Author Andersons, Leasing in Europe (Mc Graw Hill Book Company 1992) 53-54.

4 Jimenez (n 2).

5 Convention on International Interests in Mobile Equipment, (16 Nov. 2001), 2307 U.N.T.S. 285, art 1(q) [ hereinafter Cape Town Convention].

6 IAS Plus, 'IAS 17- Leases' (Deloitte) < https://www.iasplus.com/en/standards/ias/ias17> accessed 7 April 2021.

7 Donal Patrick Hanley, 'Aircraft Operating Leasing: A Legal and Practical Analysis in the Context of Public and Private International Air Law' (Doctoral Thesis, Leiden University 2011). 


\subsection{Regulations under private international air law}

UNIDROIT Convention on the International Interests in Mobile Equipment (Cape Town Convention) and its aircraft protocol is the foremost international treaty in facilitating flexible aircraft acquisition for airlines. ${ }^{8}$ To provide a unified guideline to regulate the lessor's and lessee's responsibility in cross border leasing agreements, the UNIDROIT Convention on International Financial Leasing has been formalized. ${ }^{9}$ These International covenants lay down a system of regulations that provides a standard of rules dealing from governing law to the nature of responsibility and obligations for the lessor and the lessee.

\section{a. Governing law}

The governing law in Aircraft acquisition varies across different contracts as they are bespoken to accommodate the parties' interest from different jurisdictions. ${ }^{10}$ Typically, these contracts are either governed by English common law or New York law because of abundantly available precedents, which reduces uncertainty in clarifying the position of the parties and their contractual obligations. ${ }^{11}$

The Aircraft Protocol to the Cape town convention allows the parties to choose any governing law of their preference ranging from lex situs to lex loci contractus, as per their preference in the agreement. ${ }^{12}$ To avoid renvoi, the parties can also choose International contract law, which may include UNIDROIT Principles of International Commercial Contracts by its explicit mention in the contract..$^{13}$ Therefore, under these conventions, the parties have the freedom to choose any governing law for regulating their contractual regulation concerning various obligations and remedies, which can range from domestic law to International law of contract. It is also imperative to note that as per the Cape Town Convention standards, there is also

\footnotetext{
Jefrey Wool, 'The Next Generation of International Aviation Finance Law: An Overview of the Proposed UNIDROIT Convention on International Interests in Mobile Equipment as Applied to Aircraft Equipment [1999] 20:3 U. Pa. J Int'l Econ. L 499.

9 UNIDROIT Convention on International Financial Leasing, Ottawa (28 May 1988) [hereinafter Financial Leasing Convention].

10 Goode R, Convention on International Interests in Mobile Equipment and Protocol thereto on Matters specific to Aircraft Equipment: Official Commentary (UNIDROIT 2002) 175-180.

11 Donald H Bunker, International Aircraft Financing (2d ed., International Air Transport Association 2015) 173-174.

12 Protocol to the Convention on International Interests in Mobile Equipment on Matters Specific to Aircraft Equipment, (Nov. 16, 2001), 2367 U.N.T.S. 517, art VIII [hereinafter Aircraft Protocol to Cape Town Convention].

13 Hanley (n 7) 181-182.
} 
an option of settling the issue in conformity with the general principle of laws in the absence of specific governing law. ${ }^{14}$

\section{b. Default and remedies}

The Cape Town Convention and the Convention of International Financial Leasing provide several remedies in cases of default that interact with the existing domestic remedy available under the governing law preferred by the parties in their agreement. These remedies clarify the parties' position, which coexists once these treaties have been ratified by the state of the parties involved in the aircraft acquisition contract. ${ }^{15}$

The recourse available to the lessor against the lessee under the Cape Town convention read with Aircraft Protocol includes taking repossession of the aircraft by physical transfer of the aircraft object and remarket it either by selling or leasing it, recover or collect any profit from the lessee from the use of the aircraft object. ${ }^{16}$ The Convention on financial leasing also ensures the recovery of unpaid rentals along with interest and damages from the lessee. ${ }^{17}$ Therefore, these international covenants ensure that the essential remedies are provided to safeguard the creditor's interest or the lessor, making it obligatory for the lessee to pay its dues on account of any default. ${ }^{18}$

\subsection{Standard contract clause in aircraft lease agreements}

Acquisition of aircraft by airlines based on leasing agreement irrespective of the nature of the lease typically involves three parties that are a lessor, a lessee and a supplier. The lessee enters into a supply agreement with the supplier to select the equipment for which the lessor pays in the supply agreement. After that, the lessee in exchange for the payment made by the lessor to the supplier for the equipment enters into a lease agreement to pay off his lease in a rental arrangement thereby enjoying the right to use the equipment. ${ }^{19}$ Therefore, due to the peculiar nature of the lease agreement, there are certain standard clauses contained within the agreement to ensure liquidity for the lessor to repay his debt to the supplier for the aircraft it is being financed.

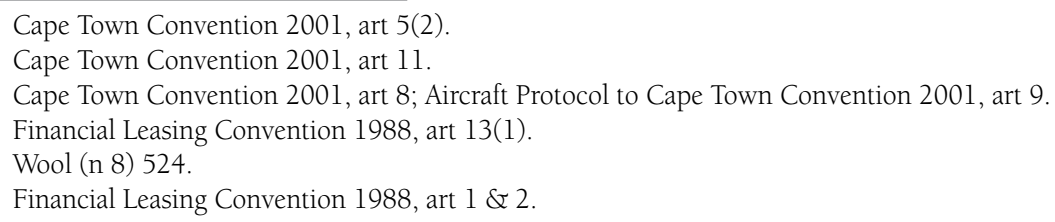


The general practice in an aircraft leasing agreement is to incorporate a "Hell-or-high water" clause which imposes an absolute obligation on the lessee irrespective of any circumstance to pay the rent for the aircraft to the lessor..$^{20}$ The duty to pay the lease becomes unconditional for the lessee. It does not consider any unforeseen circumstance that might affect the airline's ability to pay the lease. This contract clause gives an upper edge to the lessor over the lessee and obligates the lessee to honour his payment obligations.

\section{Impact of Coronavirus on the economy of airline industry}

The world economy has been severely affected due to harsh measures adopted across the globe to stop the progression of the Coronavirus. One of the immediate responses around the world since the World Health Organization declared the pandemic on 11 March 2020 is to close borders and restrict travel. ${ }^{21}$ The aviation industry has come to a near halt as per the official data wherein it has been reported that in April 2020, there was a drop of $73.7 \%$ global air traffic as compared to the previous year. ${ }^{22}$ The travel and tourism industry is deemed to be bearing the brunt of various restrictions stopping the Global movement. The airlines have suffered huge losses due to the reduction in passenger movement, which is approximately computed to have been reduced by $89 \%$ in the second quarter of 2020 globally. ${ }^{23}$

Restriction on air travel combined with flight cancellations and reduction in passenger movement has forced airlines to ground their fleet, which has significantly affected their liquidity. Due to the disruption caused by the pandemic, Lufthansa is one of biggest European airline carriers which is expected to suffer a loss of 500 million euro each month thereby causing the airline to reduce its fleet from 760 aircraft to $610 .{ }^{24}$ Almost all the major airlines have suffered because, in the second quarter of 2020, the International Airline Group reported a loss of 1,365 million euros in

$20 \quad$ Hanley (n 7) 63-64.

21 World Health Organization, 'Director-General's opening remarks at the media briefing on COVID-19' (WHO, 11 March 2020) <https://www.who.int/director-general/speeches/detail/who-director-general-s-openingremarks-at-the-media-briefing-on-covid-19---11-march-2020> accessed 10 April 2021.

22 Ian Petchenik, 'Scrapping along the Bottom: April Air Traffic Statistics' (Flightradar24, 1 May 2020) < https:// www.flightradar24.com/blog/scraping-along-the-bottom-april-air-traffic-statistics/> accessed 12 April 2021.

23 IATA Economics, 'Airline Financial Monitor' (IATA, 18 September 2020) <www.iata.org/en/iata-repository/ publications/economic-reports/airlines-financial-monitor-august-2020> accessed 12 April 2021.

24 'Pandemic bill heavier in Lufthansa' (DW made for Minds, 21 September 2020) <www.dw.com/tr/lufthansada-pandemi-faturas\%C4\%Bl-a\%C4\%9F\%C4\%Blrla\%C5\%9Ft\%C4\%B1/a-5500651l> accessed 13 April 2021 . 
their annual report. ${ }^{25}$ Despite these losses, airlines also have an additional duty to uphold, including various other unavoidable fixed charges that maintain the aircraft's airworthiness. These expenses add a significant revenue burden on the airlines as they have to pay the aircraft engineers, airline crew, airport parking charges to satisfy the requirements of the aircraft approved maintenance programme. ${ }^{26}$

Airlines have started to mitigate their cash burn through various measures like reduction in aircraft crew and salary. For instance, around 12,000 employees have been laid off by British Airlines to cut expenses during this pandemic. ${ }^{27}$ It is estimated that in the second half of 2020, airline companies are expected to burn through $\$ 77$ billion in cash. ${ }^{28}$ Several airlines have also decided to reduce their fleets, delay lease payments and delivery of the aircraft. However, due to various absolute contractual obligations within leasing agreements, airlines may have difficulty taking such actions, thereby affecting their relationship with their lessors. It is imperative to understand that the pandemic has caused strenuous financial difficulty for airline companies. Hence, it is necessary to reevaluate their contractual obligations so that the entire aviation industry could survive until business returns to normal.

\section{The principle of Force-Majeure under international commercial law}

The Force Majeure principle has been incorporated under different international treaties guiding commercial contracts, including the United Nation Convention on Contracts for the International Sale of Goods (CISG) and the UNIDROIT Principle of International Commercial Contract (UPICC).$^{29}$ Generally, the CISG convention

25 Serap Zuvin and Onur Can Ucarer, 'The Aircraft Financing Market after COVID-19' (International Bar Association, 2020) <https://www.ibanet.org/article/2cb405cf-62la-4791-809f-748f09b0402d > accessed 13April 2021.

26 Henry Kikoyo, 'Liability Management for Airlines Following Complete Shut Down of Operations or Aircraft Groundings in the Wake of Coronavirus (COVID-19)' (Brownrudnick, 26 March 2020) <https:// brownrudnick.com/alert/liability-management-for-airlines-following-complete-shut-down-of-operationsor-aircraft-groundings-in-the-wake-of-coronavirus-covid-19/> accessed 15 April 2021.

27 'How much did the Corona hit which airline company?' (DW made for Minds, 8 July 2020) <https://www. dw.com/tr/korona-hangi-havayolu-\%C5\%9Firketini-ne-kadar-vurdu/g-54488779> accessed 13 April 2021.

28 IATA Economics, 'Airline industry will continue to burn through cash until 2022' (IATA, 9 October 2020) $<$ https://www.iata.org/en/iata-repository/publications/economic-reports/airline-industry-will-continue-toburn-through-cash-until-2022> accessed 13 April 2021.

29 International Institute for the Unification of Private Law (UNIDROIT), 'Principles of International Commercial Contracts (2016)' [hereinafter UPICC]; United Nations Convention on Contracts for the International Sale of Goods (11 April 1980) 1489 UNTS 3, 19 ILM 668 [hereinafter CISG]. 
does not apply to the sale of aircraft contracts. ${ }^{30}$ Therefore, to understand the principle of Force Majeure, it is better to analyze its scope under UPICC and various other domestic law systems.

The literal translation of the word Force Majeure is "superior force" ${ }^{31}$ According to article 7.1.7 of UPICC, this relief excuses the party from performing the obligations contained within a contract depending upon the occurrence of a certain unforeseeable event beyond the control of parties. ${ }^{32}$ Such unforeseen events make it impossible for the parties to uphold the contract temporarily or permanently. ${ }^{33}$ It also includes events that occur after contract formation as subsequent impossibility such as flood, droughts, earthquake, terrorist act, etc. ${ }^{34}$ The significant consequence of such a remedy is to remove the liability regarding damages from the performing party caused due to non-performance, or sometimes it may also include prevention of performance. ${ }^{35}$ Therefore, affecting the right of the other party to enforce its obligatory advantage, which may be monetary or of any nature depending on the terms of the contract.

In English common law, this doctrine is not governed by any express legislation; rather, its application depends on the inclusion of the Force Majeure clause by the parties in a commercial contract. Such a clause has to be construed restrictively. It will contain a list of unforeseen events that arise without the interference of the parties qualifying as the Force Majeure event, allowing the party to invoke this relief. ${ }^{36}$ The practice prevalent in civil law jurisdiction regarding the use of this remedy is similar to that of the common law system. However, the contractual provision herein describes the exact conditions required for an event to be qualified as force majeure. ${ }^{37}$

John P. McMahon, 'Applying for Mangers and Counsel: Applying the CISG' (IICL, May 2010) <https://iicl. law.pace.edu/cisg/page/guide-managers-and-counsel-applying-cisg> accessed 20 April 2021.

31 Klaus Peter Berger and Daniel Behn, 'Force Majeure and Hardship in the Age of Corona: A Historical and Comparative Study' (2019-2020) 6 McGill J. D.R 77.

32 UPICC 2016, art 7.1.7.

33 Berger and Behn (n 31).

34 'Force Majeure TransLex-Principle VI 3' at VI 3 (c) <https://www.trans-lex.org/944000> accessed 20 April 2021.

35 UPICC 2016.

36 Great Elephant Corporation v Trafigura Beheer BV [2013] EWCA Civ 907 [25].

37 International Chamber of Commerce, 'ICC Force MajeureAnd Hardship Clauses 2020: Introductory Note and Commentary' (ICC, June 2020) <https://iccwbo.org/content/uploads/sites/3/2020/07/icc-forcemajeure-introductory-note.pdf> accessed 18 April 2021. 


\subsection{Pandemic as a Force Majeure event}

The scope of a Force Majeure remedy depends on an unforeseeable event as observed from the guidelines provided under international law and practice prevalent in the common and civil law system. However, there is no particular condition that may explicitly qualify a pandemic as a Force Majeure event. ${ }^{38}$ The common practice adopted by courts while understanding the application of this remedy is to interpret it strictly and literally. In 2005, China International Economic and Trade Arbitration Commission failed to consider the SARS outbreak as a Force Majeure event, thereby not allowing the parties to excuse themselves for non-performance of the obligation. ${ }^{39} \mathrm{It}$ is understood that unless there is a specific mention of the epidemic, disease and quarantine in the Force Majeure clause, it will not be applicable. ${ }^{40}$

The restrictive measures taken by the nations like lockdowns, border closure, travel restriction and quarantines to control the spread of the COVID-19 has caused varying levels of economic disruptions to the supply chain both nationally and internationally. However, it has been observed that even if there is a shift in the financial stability of the party to a contract, the courts are unlikely to accept the invocation of a Force Majeure clause. ${ }^{41}$ Under the English common law, the Commercial Court has opined that change in market circumstances affecting the ease with which the parties' obligations can be performed is not regarded as a Force Majeure event. ${ }^{42}$ The impossibility to perform due to financial suffering caused by government measures as a ground to use Force Majeure will depend upon carefully analyzing the exact reference in the contract and comparing it with government measures that are affecting the parties from fulfilling their obligations. ${ }^{43}$

38 Berger and Behn (n 31).

39 People Republic of China $v$ Netherlands [2005] CIETAC (IICL, 2005) <https://iicl.law.pace.edu/cisg/case/ china-march-5-2005-translation-available> accessed 20 April 2021.

40 Brian W. Ledebuh and others, 'COVID-19, '"Force Majeure" Clauses and Contractual Nonperformance' (2020)' XI (139) TNLR <https://www.natlawreview.com/article/covid-19-force-majeure-clauses-and-contractual-nonperformance> accessed 15 April 2021.

41 Northern Indiana Public Service Co. v Carbon County Coal Co. [7th Cir. 1986] 799 F.2d 265 [ 275].

42 Tandrin Aviation v Aero Toy Store (2010) EWHC 40(Comm).

43 'Force Majeure in Aviation Contract' (Winstan \& Strawn LLP, April 2020). <https://www.winston.com/en/ thought-leadership/force-majeure-in-aviation-contracts.html> accessed 4 April 2021. 


\subsection{Effect of absolute contractual obligation on invoking Force Majeure in aircraft leasing contract}

The airline industry has suffered substantial financial loss due to the pandemic, and it has become a daunting task for them to continue their operation in the usual manner. They are looking for a potential respite to survive the pandemic and avoid liability for default on their lease for aircraft acquired on leasing agreements. For instance, the possibility of using the remedy of Force Majeure to circumvent lease payments and minimize their cash burden until the pandemic related restriction persists. However, these lease agreements are enclosed with absolute obligations of the "Hell or High water" clause, making it questionable for airlines to invoke Force Majeure and excuse their performance.

It is improbable that a Force Majeure clause will be present in an aircraft leasing agreement. Even though it is present, its scope has to be explicitly interpreted regarding its application during a pandemic that is taken to be not a Force Majeure event. ${ }^{44}$ However, various national governments have proposed issuing a certificate to consider the pandemic as a Force Majeure occurrence which may allow the companies to breach their contractual obligations depending on satisfying the conditions for grant of such certificate. The China Council for the Promotion of International Trade approximately has issued 1600 such certificates..$^{45}$ Furthermore, various legislative amendments and notifications have been issued by the Chamber of Commerce of various European and central Asian regions like Bulgaria, Kazakhstan, Slovakia, Turkey, Ukraine and Uzbekistan, depending upon satisfying the guidelines of respective nations for issuance of a Force Majeure certificate. ${ }^{46}$

These certificates are a symbol of identifying an unforeseeable event that is the COVID-19 pandemic, but the legal consequence of these certificates is still undecided, especially in an international forum. They may apply in the national jurisdiction, but aircraft leasing agreements enclosed with absolute obligation, especially concerning lease payment, involve parties from multiple countries,

$44 \quad$ Leo Fattorini and others, 'Covid-19: Where to next for Airlines and their investors?' (Bird \& Bird, March 2020) <https://www.twobirds.com/en/news/articles/2020/global/covid19-where-to-next-for-airlines-andtheir-investors> accessed 5 April 2021.

45 Elodie Fortin, 'The Impact of coronavirus (COVID-19) on aviation finance' (LexisNexis, March 2020) <https:// www.lexisnexis.co.uk/blog/covid-19/the-impact-of-coronavirus-(covid-19)-on-aviation-finance> accessed 6 April 2021

46 'Regional: COVID-19 as Force Majeure in Aviation Contracts. Comparative Analysis across 10 Jurisdictions' (Kinstellar, March 2020) <https://www.kinstellar.com/insights/detail/1059/regional-covid-19-as-force-majeure-in-aviation-contracts-comparative-analysis-across-10-jurisdictions> accessed 6 April 2021. 
making it difficult for airlines to enforce these certificates in court legally. In Golsen v. ONG Western Inc. ${ }^{47}$ The court believed that it is an accepted principle of law that a contract must be read as a whole. In this case, the defendant took the defence of Force Majeure for failure to perform the contract, but the court held that the contract contained an absolute obligation of take-or-pay provision, which will not be overridden by Force Majeure remedy.

The rigidity of the "Hell-or-High water" is visible in the case of General Electric Capital Corp. v. FPL Services Corp. ${ }^{48}$ where despite the loss caused to the equipment by hurricane SANDY, the contract contained this clause which mandated the lessee to make payments regardless of any circumstance causing damage to the product. In Aircraft Leasing agreements, the clause was considered in ACG Acquisition XX LLC $v$ Olympic Airlines $S A,{ }^{49}$ where the lessor had failed to provide an aircraft in an airworthy condition. However, the court was of the opinion that the "Hell-or-High water" clause in the lease agreement binds the lessee to fulfil its obligation to pay the lease on an absolute basis. The lessees will have to bear all the risk in such agreements, and this clause prevents him from invoking the doctrine of Force Majeure. Therefore, irrespective of any circumstance, the lessee has to pay the rent. In the case of Celestial Aviation Trading 71 Limited $v$ Paramount Airways Private Limited, ${ }^{50}$ The English High court has held that irrespective of any defence available to the lessee, its obligation to pay the lessor could not be exempted.

Therefore, according to the prevalent judicial opinion regarding absolute contractual obligations, especially in light of the "Hell or High-water" clause, invoking the remedy of Force Majeure would be not a legally viable option available for the airline companies. The government measure taken to fight against the pandemic may be an unforeseeable event qualifying as a Force Majeure event based on an express contractual clause or by issuing the certificate. However, the spirit of the "Hell or High-water" clause ensures payment to the lessor, and there cannot be any default by the lessee as the same would make the airline company liable for damages. Even though the airlines have suffered massive financial loss due to the pandemic, they cannot invoke Force Majeure in any circumstance in a lease agreement to excuse non-performance.

\footnotetext{
[Okla. 1988]756 P.2d 12010-12014.

[ND Iowa, 2013] 986 F Supp 2d 1029 [1036].

[2012] EWHC 1070 (Comm).

[2009] EWHC 3142 (Comm) [7].
} 
However, as understood, the purpose of such absolute obligation in an aircraft leasing agreement is to ensure that the lessor is protected by making the lessee abide by the lease terms. The general principle of the Hardship doctrine can be an alternative legal remedy wherein the lessee can re-negotiate the terms of the contract to delay payment rather than completely obscuring from his obligation towards the lease. This will ensure that the lessor is paid and the lessee is relieved from the immediate burden to pay and avoid damages.

\section{The alternative remedy: Hardship doctrine under international commercial code}

The formation of a contract is based on the fundamental principle of "pacta sunt servanda", which upholds the sanctity of the contract. This principle originates from the idea of good faith and equity that ensures continued enforceability of the contract. ${ }^{51}$ The enforcement of the contract depends upon the circumstances present at the time of entering into the contract. However, the possibility of the circumstances to remain persistent is not always possible; therefore, certain defences in exceptional circumstances available for parties to a contract based on the principle of Rebus sic stantibus..$^{52}$ This principle considers the circumstantial changes that necessitate amendments in the contract to accommodate the new circumstances. ${ }^{53}$ The requirements identified by courts that dictate the application of this principle include: ${ }^{54}$

1. the radical alteration of the state of affairs changing the position of the parties different from the time of entering the contract,

2. an imbalance is created hampering the performance of the contract,

3. such alteration was unforeseeable at the time of entering into contract despite taking all the due diligence,

4. the principle is applied only in the absence of any other remedy, including no clause available in the contract.

\footnotetext{
'Hardship Trans Lex-Principle VIII' at VIII.1 <https://www.trans-lex.org/951000> accessed 15 April 2021. Berger and Behn (n 31).

Ibid.

54 'The Rebus Sic Stantibus clause in the presence of Covid-19' (Osborne Clarke, March 2020) <https://www. osborneclarke.com/insights/rebus-sic-stantibus-clause-presence-covid-19/> accessed 17 April 2021.
} 
The purpose is to rectify the imbalance between the parties by taking measures that warrant that the idea of good faith remains intact and the contract remains enforceable under new circumstances. The idea of this principle has been referred to as the Hardship doctrine in various soft legal instruments at the international and national forum as a general principle of law. ${ }^{55}$ The basis of this doctrine is the modern approach towards the lex mercatoria principle, which identifies the duty to re-negotiate if there is a need to synchronise the terms of the contract with the change in circumstances..$^{56}$

The UNIDROIT Principle of International Commercial contract defines Hardship event in article 6.2.2 as one that 'fundamentally alters the equilibrium of the contract either because the cost of a party's performance has increased or because the value of the performance a party receives has diminished. ${ }^{57}$ This definition is supplemented by the same requirement as followed in Rebus sic stantibus that is the change in equilibrium caused by an unforeseeable event after the conclusion of the contract which is beyond the control of the party and could not be accounted at the time of conclusion of the contract by the party whose position has been altered.$^{58}$ Article 6.2.3 provides the tools for curing the hardship event, which includes renegotiation and adaptation of the contract so that it remains valid. ${ }^{59}$ The request for renegotiation of the contract does not eliminate performance by the disadvantaged party. If the renegotiations fail, the parties have the option to go to court, which may terminate the contract or make changes to restore the equilibrium. ${ }^{60}$

The disadvantaged party has the right to request renegotiation of the contract when it becomes economically challenging to uphold the terms of the contract, thereby distorting the equilibrium. ${ }^{61}$ This ensures that an economic tangibility of the contract may also qualify as Hardship depending on satisfying all the legal requirements of

55 Marchisio \& Giacomo, 'Rebus Sic Stantibus: A Comparative Analysis for International Arbitration' (2012) SSRN <https://ssrn.com/abstract=210364l> accessed 22 April 2021.

56 'Duty to renegotiate Trans Lex- Principle IV.6.7' at IV.6.7 <https://www.trans-lex.org/935000> accessed 20 April 2021.

57 UPICC 2016.

58 Joern Rimke, 'Force Majeureand Hardship: Application in International Trade Practice with Specific Regard to the CISG and the UNIDROIT Principles of International Contracts' [2001] PACE REVIEW OF THE CISG 193

59 Ndubuisi Augustine Nwafor, 'Comparative and Critical Analysis of the Doctrine of Exemption/Frustration/ Force Majeureunder the United Nations Convention on the Contract for International Sale of Goods, English Law and UNIDROIT Principles' (PhD thesis, University of Stirling 2015); UPICC 2016.

60 UPICC 2016.

61 Scafom Int'l BV v. Tubes s.a.s., Case No. C.07.0289. N <http://www.unilex.info/case.cfm?pid=2\&do=case\&id=1456\&step=FullText $>$ accessed 22 April 2021. 
the doctrine. ${ }^{62}$ The characteristic feature of Hardship is the difficulty in continuing specific performance of the contract despite the excessive impact of the change of circumstances, but if the contract can adapt to this change by modification, then performance can be maintained. ${ }^{63}$ COVID-19 has caused severe economic harm to the market, making it difficult for all the stakeholders to survive, but if the business modifies according to the circumstances, then they can pull through until the pandemic ends.

\section{Application of Hardship in aircraft leasing agreement}

There might not be an express legal clause in an aircraft leasing agreement that deals with classifying a pandemic as a Hardship event. But Hardship is a general principle of law that has been codified in an international soft legal instrument called the UNIDROIT Principle of International Commercial (UPICC). ${ }^{64}$ As mentioned herein, the Cape Town Convention and the Convention on Financial Leasing have allowed the party to choose UPICC along with the general principle of law as the governing law in aircraft contracts for resolving conflicts between the parties. ${ }^{65}$

When there is no express accounting mechanism in the contract, the parties also have the discretion to choose UPICC to resolve any dispute. ${ }^{66}$ Application of UPICC in a contract to resolve a dispute will allow the parties to use the Hardship Principle.$^{67}$ In the absence of any specific reference to Hardship in the contract, the parties have a wide discretion to adopt an ad-hoc mechanism recognizing Rebus sic stantibus as part of the contract, making it applicable for them to apply the general principle of Hardship in a situation where there is a change of circumstances altering the position of the party. ${ }^{68}$ In contracts where the reference has been made to the domestic law as the governing law of the contract, the parties also have the choice of applying the general principle of law in resolving disputes which UPICC shall guide. ${ }^{69}$ Therefore, the modern approach towards the development of international

\footnotetext{
62 Nwafor (n 59).

63 Berger and Behn (n 31).

${ }^{64}$ Henry D. Gabriel, 'The Use of Soft Law in the Creation of Legal Norms in International Commercial Law: How Successful Has It Been?' [2019] 40 MICH. J. INT'L L. 413.

65 Wool (n 8) 499-500; Cape Town Convention 2001, art 5(2).

66 Award 116 of 20 January of 1997 of the International Arbitration court of the chamber of the commerce and Industry of the Russian Federation.

67 Award of 30 November of 2006 of Centro de Arbitraje de Mexico.

68 Marchisio \& Giacomo (n 55).

69 ICC award No 7365 of 5 May 1997.
} 
commercial law contributes to various mechanisms through which the remedy of Hardship can be applied in aircraft leasing agreements.

\section{Conclusion: sustainability of the aircraft leasing agreement during COVID-19.}

COVID-19 has economically affected the airline industry due to various government measures restricting travel, and along with this, they also have an additional financial burden of maintaining the aircraft. The airlines are looking for every possible remedy to reduce this burden, including avoiding lease payments for aircraft acquired on leasing agreements. The pandemic has created the possibility of invoking Force Majeure in different businesses, including the airline industry. However, considering the nature of the aircraft lease agreement, Force Majeure is not a possible solution to circumvent the "Hell-or High-water" clause as non-performance of the contract will incur the contract's termination by lessor and imposition of damages on the lessee. The spirit of this agreement is to ensure performance. Therefore, even if there is a contractual provision or government measure allowing application of Force Majeure in the lease agreement, it will not be applicable on the lease payment.

However, considering the nature of the Hardship doctrine, the COVID-19 pandemic may classify as a Hardship event for the airline industry. The purpose of applying Force Majeure to a contract is to excuse non-performance. However, Hardship allows re-negotiating the contract terms, which ensures the contract is kept alive although on revised terms. The occurrence of the COVID-19 is an unforeseeable event which the aviation industry could not have accounted for during the formation of the contract. Further, the economic difficulties suffered by the airline industry because of the pandemic has shifted the equilibrium in the aircraft leasing agreements putting the airlines into a disadvantageous position. Therefore, airlines have the right to call for renegotiation of the lease payment requirement with the lessor to restore balance of obligations in the lease agreement. This will ensure that there is no exemption from performance, upholding the essence of the "hell or high-water" clause and providing immediate relief for the airline industry. Hence, applying Hardship over Force Majeure is a more viable legal solution for the airline industry in the aircraft leasing agreement. The same can be contractually invoked by taking guidance from modern interpretation of international commercial law.

As the pandemic progresses, the development in vaccination programmes boosts the recovery of the travel and tourism industry. The aviation industry is slowly recovering, 
but the fear of multiple waves persists and does not absolve the financial issues of the airline industry. The passenger airlines have remodeled their aircraft into cargo flights to raise liquidity, and various governments have also provided financial aid to the airlines to continue operation. However, most aircraft are operated on lease agreements by the airline industry and liability to pay the lease is a cumbersome burden that the airlines have to follow irrespective of any circumstance. Therefore, Hardship is the only way that allows the airlines to re-negotiate the agreement and sustain the contract during the pandemic.

\section{Bibliography:}

Award 116 of 20 January of 1997 of the International Arbitration Court of the chamber of the commerce and Industry of the Russian Federation.

Award of 30 November of 2006 of Centro de Arbitraje de Mexico.

Berger, Klaus Peter and Behn, Daniel, 'Force Majeure and Hardship in the Age of Corona: A Historical and Comparative Study' (2019-2020) 6 McGill J. D.R 77.

'Force Majeure TransLex-Principle VI 3' at VI 3 (c) <https://www.trans-lex.org/944000> accessed 20 April 2021.

Bunker, Donald H. International Aircraft Financing (2d edInternational Air Transport Association 2005) ISBN-10†: ‘9291954365

Convention on International Interests in Mobile Equipment, (16 Nov. 2001), 2307 U.N.T.S. 285, art 1(q) [ hereinafter Cape Town Convention].

Endrizalova, Eva and others, 'Operating Lease as a Specific Form of Airlines Outsourcing' (18th international scientific conference Business Logistics in Modern Management, November 2018). <https://www.researchgate.net/publication/328829802_Operating_Lease_As_A_Specific_Form_Of_Airlines_Outsourcing > accessed 2 April 2021.

Duty to renegotiate Trans Lex-Principle IV.6.7' at IV.6.7 <https://www.trans-lex.org/935000> accessed 20 April 2021.

Fattorini, Leo and others, 'Covid-19: Where to next for Airlines and their investors?' (Bird

\& Bird, March 2020) <https://www.twobirds.com/en/news/articles/2020/global/ covid19-where-to-next-for-airlines-and-their-investors> accessed 5 April 2021.

'Force Majeure in Aviation Contract' (Winstan \& Strawn LLP, April 2020). <https:// www.winston.com/en/thought-leadership/force-majeure-in-aviation-contracts.html> accessed 4 April 2021.

Fortin, Elodie 'The Impact of coronavirus (COVID-19) on aviation finance' (LexisNexis, March 2020) <https://www.lexisnexis.co.uk/blog/covid-19/the-impact-of-coronavirus(covid-19)-on-aviation-finance> accessed 6 April 2021.

Great Elephant Corporation v Trafigura Beheer BV [2013] EWCA Civ 907 [25]. 
Goode R, Convention on International Interests in Mobile Equipment and Protocol thereto on Matters specific to Aircraft Equipment: Official Commentary (UNIDROIT 2002) 175-180. Hardship Trans Lex-Principle VIII' at VIII.1 <https://www.trans-lex.org/951000> accessed 15 April 2021.

Hanley, D. P. Aircraft operating leasing: a legal and practical analysis in the context of public and private international air law. (2011, November 24). Retrieved from https://hdl. handle.net/1887/18146

Henry D. Gabriel, The Use of Soft Law in the Creation of Legal Norms in International Commercial Law: How Successful Has It Been?, 40 MICH. J. INT'L L. 413 (2019). Available at: https://repository.law.umich.edu/mjil/vol40/iss3/3

'How much did the Corona hit which airline company?' (DW made for Minds, 8 July 2020) <https://www.dw.com/tr/korona-hangi-havayolu-\%C5\%9Firketini-ne-kadarvurdu/g-54488779> accessed 13 April 2021.

IAS Plus, 'IAS 17- Leases' (Deloitte) < https://www.iasplus.com/en/standards/ias/ias17> accessed 7 April 2021.

IATA Economics, 'Airline industry will continue to burn through cash until 2022' (IATA, 9 October 2020) <https://www.iata.org/en/iata-repository/publications/economicreports/airline-industry-will-continue-to-burn-through-cash-until-2022> accessed 13 April 2021.

IATA Economics, 'Airline Financial Monitor' (IATA, 18 September 2020) <www.iata.org/en/ iata-repository/publications/economic-reports/airlines-financial-monitor-august-2020> accessed 12 April 2021.

ICC award No 7365 of 5 May 1997.

International Institute for the Unification of Private Law (UNIDROIT), 'Principles of International Commercial Contracts (2016)' [hereinafter UPICC]; United Nations Convention on Contracts for the International Sale of Goods (11 April 1980) 1489 UNTS 3, 19 ILM 668 [hereinafter CISG]

International Sale of Goods (11 April 1980) 1489 UNTS 3, 19 ILM 668 [hereinafter CISG]. International Chamber of Commerce, 'ICC Force MajeureAnd Hardship Clauses 2020: Introductory Note and Commentary' (ICC, June 2020) <https://iccwbo.org/content/ uploads/sites/3/2020/07/icc-forcemajeure-introductory-note.pdf> accessed 18 April 2021.

Jimenez, Hortencia 'Commercial Aircraft Leasing and its Booming Complexities' (MSc. Aviation Administration thesis, Middle Tennessee State University 2017).

Kikoyo, Henry, 'Liability Management for Airlines Following Complete Shut Down of Operations or Aircraft Groundings in the Wake of Coronavirus (COVID19)' (Brownrudnick, 26 March 2020) <https://brownrudnick.com/alert/ 
liability-management-for-airlines-following-complete-shut-down-of-operations-oraircraft-groundings-in-the-wake-of-coronavirus-covid-19/> accessed 15 April 2021.

Lease Europe and Author Andersons, Leasing in Europe (McGraw Hill Book Company 1992) 53-54.

Ledebuh, Brian W. and others, "COVID-19, "Force Majeure" Clauses and Contractual Nonperformance' (2020)' XI (139) TNLR <https://www.natlawreview.com/article/ covid-19-force-majeure-clauses-and-contractual-nonperformance> accessed 15 April 2021.

Marchisio, Giacomo, Rebus Sic Stantibus: A Comparative Analysis for International Arbitration (July 11, 2012). Available at SSRN: https://ssrn.com/abstract=2103641 or http://dx.doi.org/10.2139/ssrn.2103641

McMahon, John P. 'Applying for Managers and Counsel: Applying the CISG' (IICL, May 2010) <https://iicl.law.pace.edu/cisg/page/guide-managers-and-counsel-applying-cisg> accessed 20 April 2021.

Northern Indiana Public Service Co. v Carbon County Coal Co. [7th Cir. 1986] 799 F.2d 265 [275].

Nwafor, Ndubuisi Augustine Comparative and Critical Analysis of the Doctrine of Exemption/ Frustration/Force Majeure under the United Nations Convention on the Contract for International Sale of Goods, English Law and UNIDROIT Principles' (PhD thesis, University of Stirling 2015);

Pandemic bill heavier in Lufthansa' (DW made for Minds, 21 September 2020) <www. dw.com/tr/lufthansada-pandemi-faturas\%C4\%Bl-a\%C4\%9F\%C4\%Blrla\%C5\%9Ft $\%$ C4\%B1/a-55006511> accessed 13 April 2021.

People Republic of China v Netherlands [2005] CIETAC (IICL, 2005) <https://iicl.law.pace. edu/cisg/case/china-march-5-2005-translation-available> accessed 20 April 2021.

Petchenik, Ian 'Scrapping along the Bottom: April Air Traffic Statistics' (Flightradar24, 1 May 2020) < https://www.flightradar24.com/blog/scraping-along-the-bottom-aprilair-traffic-statistics/> accessed 12 April 2021.

Protocol to the Convention on International Interests in Mobile Equipment on Matters Specific to Aircraft Equipment, (Nov. 16, 2001), 2367 U.N.T.S. 517, art VIII [hereinafter Aircraft Protocol to Cape Town Convention].

Regional: COVID-19 as Force Majeurein Aviation Contracts. Comparative Analysis across 10 Jurisdictions' (Kinstellar, March 2020) <https://www.kinstellar.com/insights/ detail/1059/regional-covid-19-as-force-majeure-in-aviation-contracts-comparativeanalysis-across-10-jurisdictions> accessed 6 April 2021.

Rimke, Joern. Force Majeure and Hardship: Application in International Trade Practice with Specific Regard to the CISG and the UNIDROIT Principles of International Commercial Contracts" in Pace International Law Review (ed) Review of the Convention 
on Contracts for the International Sale of Goods (CISG) 1999-2000 (Kluwer, The Hague, 2001) 197, 219

Scafom Int'l BV v. Tubes s.a.s., Case No. C.07.0289.N <http://www.unilex.info/case.cfm? pid=2\&do=case\&id=1456\&step=FullText $>$ accessed 22 April 2021.

Tandrin Aviation v Aero Toy Store Neutral Citation Number: [2010] EWHC 40 (Comm) Case No: CLAIM NO. 2009 / FOLIO 206

The Rebus Sic Stantibus clause in the presence of Covid-19' (Osborne Clarke, March 2020)<https://www.osborneclarke.com/insights/rebus-sic-stantibus-clause-presencecovid-19/> accessed 17 April 2021.

UNIDROIT Convention on International Financial Leasing, Ottawa (28 May 1988) [hereinafter Financial Leasing Convention].

Wool, Jefrey 'The Next Generation of International Aviation Finance Law: An Overview of the Proposed UNIDROIT Convention on International Interests in Mobile Equipment as Applied to Aircraft Equipment' [1999] 20:3 U. Pa. J Int'l Econ. L 499.

World Health Organization, 'Director-General's opening remarks at the media briefing on COVID-19' (WHO, 11 March 2020) <https://www.who.int/director-general/ speeches/detail/who-director-general-s-opening-remarks-at-the-media-briefing-oncovid-19---11-march-2020> accessed 10 April 2021.

Zuvin, Serap and Can Ucarer, Onur 'The Aircraft Financing Market after COVID-19' (International Bar Association, 2020) <https://www.ibanet.org/article/2cb405cf-62la4791-809f-748f09b0402d > accessed 13April 2021. 